\title{
Pearson Correlation Analysis of Population Density and Rainfall toward Dengue Hemorrhagic Fever (DHF) West Sumatera
}

\author{
Nurdin $^{1}$, Cici Aprilliani ${ }^{1}$, Fallah Annisa ${ }^{1}$ \\ \{Nurdin@fdk.ac.id ciciapriliani@fdk.ac.id fallahannisa@fdk.ac.id\} \\ Public Health Departement of STIKes Fort De Kock Bukittinggi ${ }^{\mathbf{1 , 2 , 3}}$
}

\begin{abstract}
The highest incidence of Dengue Hemorrhagic Fever (DHF) in West Sumatra Province from 2014 to 2017 is in 2016 with 3,952 cases. Then, the lowest one is in 2014 (2,282 cases). The purpose of this research was to determine the correlation between population density and rainfall toward DHF in West Sumatra Province in 2014-2017. Quantitative research methods by using Pearson Correlation test and secondary data. The populations were the cases of DHF in West Sumatra Province from 2014 to 2017. The Samples were 76 cases. Univariate and bivariate had been used to analyze the data by using Pearson correlation test with $\alpha=0.05$. From the results of this research, it can be concluded that there were $74(97.4 \%)$ cases of DHF and $2(2.6 \%)$ the DHF cases did not find. The highest population density in 2014-2017 was less dense population (51-250 people), $36(47.4 \%)$. The rainfall in 2014-2017, there were 58 (76.3) districts or cities were in medium rainfall $(101-300 \mathrm{~mm})$. Moreover, there was a correlation between rainfall $(\mathrm{p}=0.015$ and $\mathrm{r}=0.279)$ toward DHF incidence and there was no correlation between population density $(\mathrm{p}=0.913$ and $\mathrm{r}=0.013)$ toward the incidence of DHF. In short, that rainfall is the most influence factor toward DHF. It is expected to the community to do some efforts to prevent dengue fever.
\end{abstract}

Keywords : : Pearson Correlation, DHF, Population Density, Rainfall

\begin{abstract}
1 Introduction
Dengue hemorrhagic fever (DHF) is a disease caused by dengue virus which is classified as Arthropod-Borne virus, genus Flavivirus, and family Flaviviridae. DHF is transmitted by mosquito bites from the genus Aedes, especially Aedes aegypti or Aedes albopictus. DHF can appear throughout the year and can affect all age groups. This disease is related to environmental conditions and people's behavior [1]. DHF is one of the public health problems in Indonesia where the number of sufferers tends to increase and the spread becomes wider. Dengue fever has a very fast journey and often becomes fatal because many patients die from late treatment. DHF is also called dengue hemorrhagic fever (DHF), dengue fever (DF), dengue fever (DD), and dengue shock syndrome (DSS) [2].
\end{abstract}

According to David Bylon (1779), in (Widoyono, 2011, p.72) the epidemiology of dengue 
in Batavia is caused by three main factors, namely viruses, humans, mosquitoes. Mosquitoes which become vector of DHF disease are mosquitoes which become infected while biting sick humans and viremia (there are viruses in their blood) [3]. The causes of DHF until now are known to be 4 virus serotypes, namely Dengue 1 isolated by Sabin in 1944 (DEN-1), Dengue 2 isolated by Sabin in 1944 (DEN-2), Dengue 3 isolated by Sather ( DEN-3), Dengue 4 is isolated by Satherm (DEN-4). (Masriadi, 2014). The four types of virus are found in Indonesia, in DHF endemic areas and a person can be infected with all virus serotypes at the same time [4].

Mosquitoes Aedes aegypti Adultare smaller than the average for other mosquitoes. The mosquito has a black base with white spots on the body, legs and wings.mosquito Aedes aegypti Malesucking plant fluids pollen for the purpose of his life, while the females suck blood. Female mosquitoes prefer human blood than animals [5]. Usually female mosquitoes look for prey during the day. Female mosquito biting activity is usually in the morning at 9:00 to 10:00 until evening 16:00 to 17:00. Aedes aegypti has the habit of sucking blood repeatedly to fill his stomach with blood. The mosquito is very infective as an infectious disease. After sucking blood, the mosquito alighted (rested) inside or outside the house. The preferred landings are hanging objects and usually in a rather dark and humid place [6].

In Indonesia in 2014, there were 100,347 dengue cases with 907 deaths. (MoH RI, 2014, p.153). In 2015, there were 129,650 dengue cases with 1071 deaths. (MoH RI, 2015, p.188). in 2016 the number of dengue cases increased by 204,171 cases with 1598 deaths. (RI Ministry of Health, 2016, p.179). In addition, in 2017 the number of DHF cases decreased from the previous year of 68,407 cases with 493 deaths [7]. Based on data from the Health Office of West Sumatra Province, it is know that the number of dengue cases in West Sumatra in 2014 amounted to 2,282 cases with 12 deaths. (West Sumatra Provincial Health Office, 2014, p.25). In 2015, the number of dengue cases was 3,886 cases with 29 deaths. (West Sumatra Provincial Health Office, 2015, p.27). In 2016 dengue cases increased by 3,952 cases with 21 deaths. (West Sumatra Provincial Health Office, 2016, p.26). And in 2017 the number of dengue cases decreased from the previous year of 2,755 cases with a number of deaths of 6 people [8].

Dense population allows dengue transmission to increase. (Suhermanto, 2017, p.81). Aedesaegypty because they are domestic short flight distance (100 meters). If the houses are close to each other eating mosquitoes easily move from one house to another [9]. Not only population density, the climate can also increase dengue transmission such as rainfall which affects the life of mosquitoes, mainly related to being able to increase breeding places. Rainfall can increase the density of mosquitoes, every millimeter can increase the density of mosquitoes by 1 tail. But if the amount of rainfall reaches $140 \mathrm{~mm}$ in a week then the larvae drift and die [10]. Based on the background above, the researchers are interested in conducting research on Pearson correlation analysis in determining the relationship of population density and rainfall with the occurrence of DHF in the province of West Sumatra in 2014 - 2017.

\section{Method}

This research is to determine the strong relationship between population density and rainfall with the incidence of dengue in the province of West Sumatra in 2014 until 2017. Data taken is secondary data from 2014 to 2017, when data collection was conducted in November 2018 - February 2019. The population of this study is to add 19 cities / regencies in West Sumatra 
in 2014 up to 2017 totaling 76 populations; the sample was taken using a total population that is adding up 19 cities / regencies over the last 4 years from 2014 to 2017 with a total number of 76 samples. This research is a quantitative study using the Pearson Correlation test.

\section{Result}

\section{1 . Univariate Analysis}

\subsubsection{Distribution of Dengue Heamoragic Fever Incidens}

DHF cases in West Sumatra Province in the past four years had trouble where in 2014 there were 2,282 cases with a total of 12 deaths. In 2015 the number of dengue cases increased by 3,886 cases with 29 deaths. In 2016 dengue cases increased by 3,952 cases with 21 deaths. In addition, in 2017 the number of dengue cases decreased from the previous year of 2,755 cases with a number of deaths of six people.

Table I Occurrence of Dengue Based on data from the District / City Of West Sumatra Province 2014 - 2017

\begin{tabular}{clcccc}
\hline No & District/ City & $\mathbf{2 0 1 4}$ & $\mathbf{2 0 1 5}$ & $\mathbf{2 0 1 6}$ & $\mathbf{2 0 1 7}$ \\
\hline 1 & Mentawai Island & 0 & 0 & 22 & 1 \\
2 & Pesisir Selatan district & 282 & 196 & 284 & 284 \\
3 & Solok district & 64 & 202 & 41 & 93 \\
4 & Sijunjung district & 54 & 238 & 120 & 141 \\
5 & Tanah Datar district & 279 & 396 & 268 & 230 \\
6 & Padang pariaman district & 103 & 172 & 191 & 77 \\
7 & Agam district & 161 & 280 & 438 & 125 \\
8 & Lima Puluh Kota district & 147 & 190 & 221 & 215 \\
9 & Pasaman district & 67 & 106 & 137 & 326 \\
10 & Solok Selatan district & 19 & 62 & 161 & 98 \\
11 & Dharmasraya district & 35 & 160 & 349 & 60 \\
12 & West Pasaman district & 114 & 108 & 109 & 43 \\
13 & Padang city & 666 & 1126 & 991 & 608 \\
14 & Solok city & 50 & 96 & 96 & 44 \\
15 & Sawahlunto city & 41 & 170 & 205 & 180 \\
16 & Padang Panjang city & 7 & 56 & 66 & 14 \\
17 & Bukittinggi city & 139 & 141 & 106 & 69 \\
18 & Payakumbuh city & 9 & 31 & 108 & 65 \\
19 & Pariaman city & 45 & 156 & 119 & 82 \\
& Total & 2.282 & 3.886 & 3.952 & 2.282 \\
\hline
\end{tabular}

Like West Sumatra, the prevalence of DHF in each Regency / City also tends to decrease 
/ increase every year. The results of the 2014 survey showed that districts / cities with the lowest DHF occurrence found in the Mentawai Islands Regency with zero cases, while the highest DHF occurrence was in Padang City with 666 cases. In 2015, the lowest prevalence of DHF found in the Mentawai Islands District, which was zero cases and the highest was in Padang City, which was 1126 cases. In 2016, the lowest DHF occurrence rate found in the Mentawai Islands District with 22 cases and the highest was in Padang City with 991 cases. Whereas in 2017 the lowest incidence of DHF found in the Mentawai Islands District, which was one case and the highest was in Padang City, which was 608 cases. Based on data from 3 years above, Padang City is the highest City of DHF incidence and the lowest in the Mentawai Islands. The univariate results of this study are:

Table 2: Frequency Distribution of DHF Occurrence Numbers by Regency / City in West Sumatra Province 2014-2017

\begin{tabular}{|c|c|c|c|c|c|c|c|c|c|c|}
\hline \multirow{2}{*}{$\begin{array}{c}\text { DHF } \\
\text { Incident }\end{array}$} & \multicolumn{2}{|c|}{2014} & \multicolumn{2}{|c|}{2015} & \multicolumn{2}{|c|}{2016} & \multicolumn{2}{|c|}{2017} & \multicolumn{2}{|c|}{ Total } \\
\hline & $\mathbf{f}$ & $\%$ & $\mathbf{f}$ & $\%$ & $\mathbf{f}$ & $\%$ & $\mathbf{f}$ & $\%$ & $\mathbf{f}$ & $\%$ \\
\hline Have & 18 & 94,7 & 18 & 94,7 & 19 & 100 & 19 & 100 & 74 & 97,4 \\
\hline Did not Have & 1 & 5,3 & 1 & 5,3 & 0 & 0 & 0 & 0 & 2 & 2,6 \\
\hline Total & 19 & 100 & 19 & 100 & 19 & 100 & 19 & 100 & 76 & 100 \\
\hline
\end{tabular}

Based on table 2 it can be seen that from 76 sample of districts / cities, the number of DHF events in 2014 there were 18 (94.7\%) districts / cities that had DHF incident and $1(5.3 \%)$ which did not have DHF events, In 2015 there were 18 (94.7\%) that had DHF incidents and 1 (5.3\%) that did not have DHF incidents, in 2016 all district, there were DHF incidents, namely 19 (100\%) district/ Cities, and in 2017 there were 19 (100\%) district /cities that had DHF incident.

\subsubsection{Distribution of Frequency of Population Density}

Table 3 Distribution of Frequency of Population District / City In West Sumatra Province in 2014-2017 Population Density

\begin{tabular}{|c|c|c|c|c|c|c|c|c|c|c|}
\hline \multirow{2}{*}{$\begin{array}{c}\text { Population } \\
\text { Density }\end{array}$} & \multicolumn{2}{|c|}{2014} & \multicolumn{2}{|c|}{2015} & \multicolumn{2}{|c|}{2016} & \multicolumn{2}{|c|}{2017} & \multicolumn{2}{|c|}{ Total } \\
\hline & $\mathbf{f}$ & $\%$ & $\mathbf{f}$ & $\%$ & $\mathbf{F}$ & $\%$ & f & $\%$ & $\mathbf{f}$ & $\%$ \\
\hline $\begin{array}{c}\text { Non - dense } \\
(0-50)\end{array}$ & 2 & 10,5 & 2 & 10,5 & 2 & 10,5 & 2 & 10,5 & 8 & 10,5 \\
\hline $\begin{array}{l}\text { Less Dense } \\
(51-250)\end{array}$ & 9 & 47,4 & 9 & 47,4 & 9 & 47,4 & 9 & 47,4 & 36 & 47,4 \\
\hline $\begin{array}{c}\text { Fairly Dense } \\
(251-400)\end{array}$ & 2 & 10,5 & 2 & 10,5 & 2 & 10,5 & 2 & 10,5 & 8 & 10,5 \\
\hline $\begin{array}{l}\text { Very Dense } \\
\quad(>410)\end{array}$ & 6 & 31,6 & 6 & 31,6 & 6 & 31,6 & 6 & 31,6 & 24 & 31,6 \\
\hline Total & 19 & 100 & 19 & 100 & 19 & 100 & 19 & 100 & 76 & 100 \\
\hline
\end{tabular}


According to Base on table 3 can be seen from 76 sample districts / cities, population density from 2014-2017 has 4 categories, namely non-dense categories (0-50 inhabitants), less dense (51-250 inhabitants, fairly dense (251-400 inhabitants), and very dense > 410 inhabitants). In 2014 the highest population density was in the less dense population category (51-250 inhabitants), which was found in 9 (47.4\%) districts / cities. In 2015 the highest population density was in the less dense population category (51-250 inhabitants), which was found in nine (47.4\%) districts / cities. In 2016 the highest population density was in the less dense population category (51-250 inhabitants), which was found in nine (47.4\%) districts / cities. In addition, in 2017 the highest population density is still in the category of less dense population (51-250 people) which found in nine $(47.4 \%)$ districts / cities. So it can be concluded that during the last 4 years the highest population density was found in the category of less dense population (51-250 inhabitants), namely 36 (47.4\%) districts / cities in West Sumatra Province.

\subsubsection{Rainfall Frequency Distribution}

Table 4 Rainfall Frequency Distribution by district / city In West Sumatra Province 2014-

\begin{tabular}{|c|c|c|c|c|c|c|c|c|c|c|}
\hline \multicolumn{11}{|c|}{2017} \\
\hline \multirow{2}{*}{$\begin{array}{c}\text { Rainfall } \\
(\mathbf{m m})\end{array}$} & \multicolumn{2}{|c|}{2014} & \multicolumn{2}{|c|}{2015} & \multicolumn{2}{|c|}{2016} & \multicolumn{2}{|c|}{2017} & \multicolumn{2}{|c|}{ Total } \\
\hline & f & $\%$ & f & $\%$ & f & $\%$ & f & $\%$ & f & $\%$ \\
\hline $\begin{array}{c}\text { Lower } \\
(0-100)\end{array}$ & 0 & 0 & 1 & 5,3 & 0 & 0 & 0 & 0 & 1 & 1,3 \\
\hline $\begin{array}{l}\text { Medium } \\
(101-300)\end{array}$ & 15 & 78,9 & 15 & 78,9 & 13 & 68,4 & 15 & 78,9 & 58 & 76,3 \\
\hline $\begin{array}{c}\text { High } \\
(301-500)\end{array}$ & 4 & 21,1 & 3 & 15,8 & 5 & 26,3 & 4 & 21,1 & 16 & 21,1 \\
\hline $\begin{array}{l}\text { Very High } \\
(>500)\end{array}$ & 0 & 0 & 0 & 0 & 1 & 5,3 & 0 & 0 & 1 & 1,3 \\
\hline Total & 19 & 100 & 19 & 100 & 19 & 100 & 19 & 100 & 76 & 10 \\
\hline
\end{tabular}

Based high rainfall (301-500 mm), and cu Rain is very high (> $500 \mathrm{~mm}$ ). In 2014 the highest rainfall was found in 15 (78.9) districts / cities in the medium rainfall (101300). In 2015 the highest rainfall was found in 15 (78.9) districts / cities in the medium rainfall (101-300 mm). In 2016 the highest rainfall was found in 13 (768.4) districts / cities in the medium rainfall (101-300 mm). In addition, in 2017 the highest rainfall is found in 15 (78.9) districts / cities are in the medium rainfall (101-300 mm). So it can be concluded during the last 4 years there are 58 (76.3) districts / cities that are in medium rainfall (101-300 $\mathrm{mm})$.

\subsubsection{DHF Trend}


Graph 1. DHF Trend in 2014 - 2017 in West Sumatra

Province

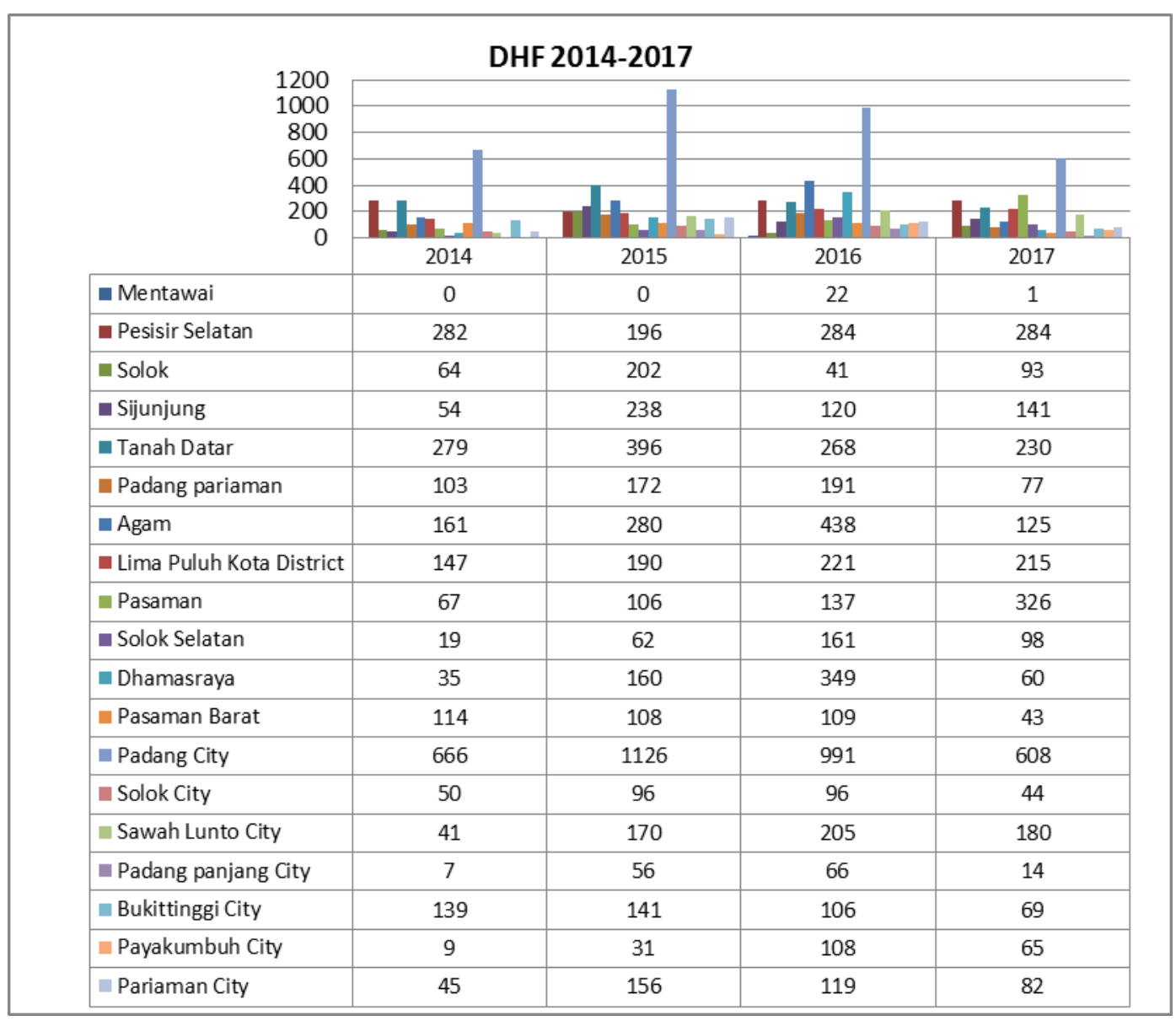

Garph 5.1 shows the trend of DHF events in West Sumatra Province from 2014-2017 experiencing fluctuations, where in 2014 Padang City was the 1st highest city with no incident cases DHF, there are 666 cases, South Coast is the highest 2, 282 cases, Tanah Datar is the highest 3, 279 cases, and there are no DHF events in Mentawai. In 2015 the city of Padang was still the highest city in which there were DHF cases, namely 1126 cases, Tanah Datar was the highest 2, there were 396 cases, the highest religion was 3, there were 280 cases, and there were no DHF events in Mentawai. In 2016, Kota Padang was the city that still had the highest 1 case of DHF, namely 991 cases, Agam was the highest 2, there were 438 cases, the highest Dhamasraya was 3, 
there were 349 cases, while the lowest cases in 2016 were in Mentawai with 22 cases. And in 2017 the city of Padang is still ranked first with the highest cases of DHF that is 608 cases, Pasaman is the highest 2, there are 326 cases, South Coastal highest is 3, there are 284 cases and the lowest is in Mentawai with 1 DHF incident. Therefore, it can be concluded from 2014-2017 Padang City is the city that has the highest incidence of DHF during the last 4 years, and Mentawai has the lowest case over the past 4 years.

\subsubsection{Trend of Population Density}

Graph 2. Population Density Trend of 2014-2017 in West Sumatra Province

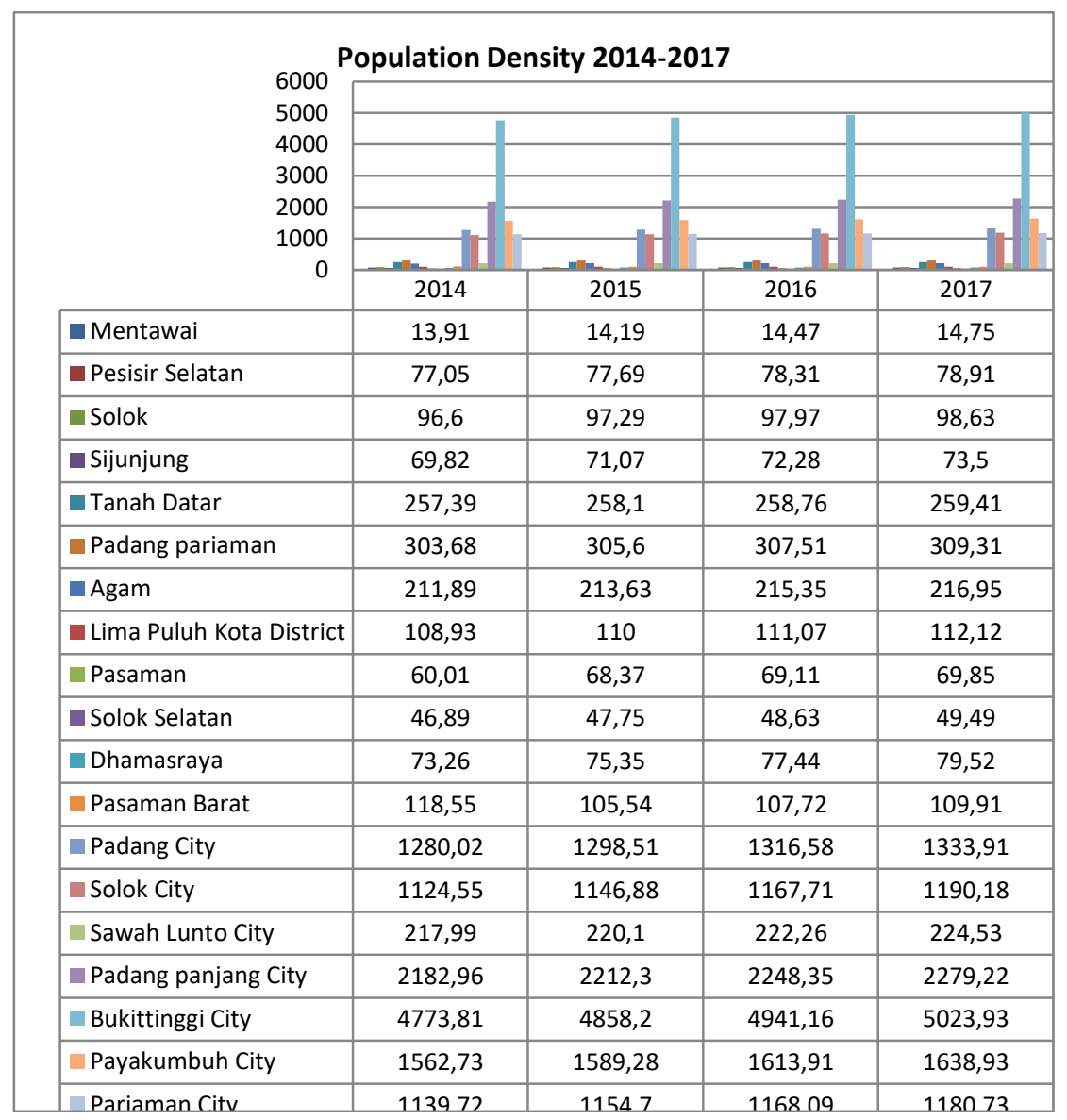

In 2014 the highest one was found in Bukittinggi by 4773.81 people, the highest 
population density was 2 in Padang Panjang City by 2182.96 people, population density the highest was found in Payakumbuh City by 1562.73 people, and the lowest population density was in Mentawai by 13.91 inhabitants. In 2015, the highest population density 1 was in Bukittinggi at 4858.2 people, the highest population density 2 was in Padang Panjang City at 2212.3 people, the highest population density 3 was in Payakumbuh City at 1589.28 people, and the lowest population density there are in Mentawai amounting to 14.19 inhabitants. In 2016, the highest population density 1 was in Bukittinggi City with 4941.16 inhabitants, the highest population density 2 was in Padang Panjang City with 2248.35 inhabitants, the highest population density 3 was in Payakumbuh City with 1613.91 inhabitants, and the lowest population density there are in Mentawai amounting to 14.47 inhabitants. In addition, in 2017 the highest population density 1 is still in Bukittinggi City by 5023.9 people, the highest population density 2 is in Padang Panjang City by 2279.22 people, the highest population density 3 is in Payakumbuh City by 1638.93 people, and population density the lowest was founded in Mentawai with 14.75 inhabitants. Therefore, it can be concluded that the population density during the last 4 years the highest population is in the city of Bukittinggi where every year has increased, and the lowest density is found in Mentawai.

\subsubsection{Rainfall Trend}

Graph 3. Rainfall Trend in West Sumatra Province in $2014-2017$ 


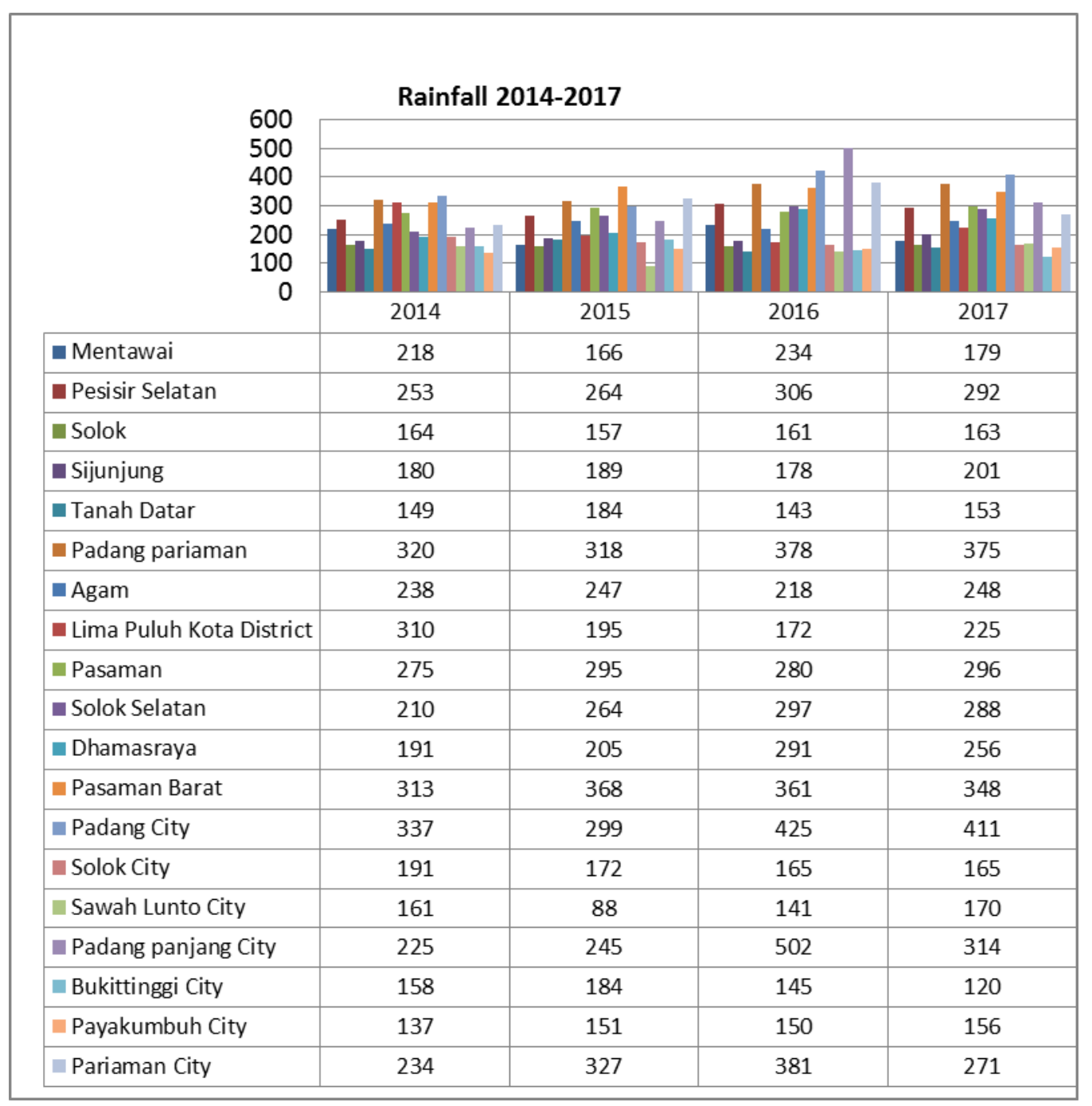

In 2014 the highest rainfall was found in the city of Padang which was $337 \mathrm{~mm}$ which was in the characteristics of high rainfall, the highest rainfall 2 was found in Padang Pariaman namely $320 \mathrm{~mm}$ which is in high rainfall, the highest rainfall 3 is in West Pasaman which is 313 $\mathrm{mm}$ which is in high rainfall, and the lowest is in Payakumbuh City which is $137 \mathrm{~mm}$ which is in medium rainfall. In 2015 the highest rainfall 1 was in West Pasaman which was 368 mm which was in the characteristics of high rainfall, the highest rainfall 2 was in Kota Pariaman which was $327 \mathrm{~mm}$ which was in high rainfall, the highest rainfall 3 was in Padang Pariaman which was 318 
$\mathrm{mm}$ which is in high rainfall, and the lowest is in Sawah Lunto City which is $88 \mathrm{~mm}$ which is in low rainfall. In 2016 the highest rainfall 1 was in the city of Padang Panjang which is $502 \mathrm{~mm}$ which is in the characteristics of very high rainfall, the highest rainfall 2 was in the city of Padang which was $425 \mathrm{~mm}$ which was in the high rainfall, the highest rainfall 3 was in Kota Pariaman namely $381 \mathrm{~mm}$ which is in high rainfall, and the lowest is in Sawah Lunto City which is $141 \mathrm{~mm}$ which is in medium rainfall. And in 2017 the highest rainfall 1 is in Padang City which is $411 \mathrm{~mm}$ which is on the characteristics of high rainfall, the highest rainfall 2 is in Padang Pariaman which is $375 \mathrm{~mm}$ which is at high rainfall, the highest rainfall 3 is in West Pasaman namely $348 \mathrm{~mm}$ which is in the high rainfall, and the lowest is in Bukittinggi City which is $120 \mathrm{~mm}$ which is in the medium rainfall It was concluded that during the last 4 years, the highest rainfall 1 in the past 2 years was in the City of Padang, high 2 in Padang pariaman, and the lowest rainfall 2 years behind is found in Sawah Lunto City.

\subsection{Bivariate Analysis}

Bivariate analysis was performed to see the strength of the relationship between the independent variable and the dependent variable, namely the strong relationship between population density, rainfall and the occurrence of DHF. Hypothesis testers for decision making about whether the proposed hypothesis by using the Pearson correlation test. The relationship between the independent variable and the dependent variable is said to be meaningful or related if the value $p$ obtained $<0.05$. The results of the bivariate analysis in this study are:

\subsubsection{Relationship and Strength of Relationship Population Density, Rainfall with Occurrence of DHF}

Table 5. Relationship and Strength of Relationship Population Density, Rainfall with Occurrence of DHF in West Sumatra 2014 - 2017

\begin{tabular}{llll}
\hline Variabel & N & P value & Nilai r \\
\hline Population density & 76 & 0,913 & 0,013 \\
Rain fall & 76 & 0,015 & 0,279 \\
\hline
\end{tabular}

Based on table 5 it can be seen that the population density with the occurrence of DHF is not significant with a sig value of 0.913. It means $0.913>0.05$ and thus the correlation between the two variables is not significant, so the strength of the relationship cannot be analyzed. Based on table 5.6 it can be seen that rainfall with the occurrence of DHF is significant with sig value of 0.015 . It means $0.015<0.05$ and thus the correlation between the two variables is significant, with the value of the correlation coefficient (Strength of Relationship) is 0.279 meaning the correlation 
coefficient is weak with the direction of a positive relationship. Which means the higher the rainfall, the incidence of DHF is increasing.

\section{Discussion}

\subsection{Univariate Analysis DHF Incident}

The results of the research conducted by researchers, obtained that from 76 samples, there were DHF events in 2014 there were 18 (94.7\%) districts / cities that had DHF events and 1 (5.3 \%) Regencies / Cities that did not have DHF events, namely in Mentawai, in 2015 there were 18 (94.7\%) Regencies / Cities that had DHF events and one (5.3\%) District / Cities that did not have DHF events, namely in Mentawai, in 2016 all Regencies / Cities had DHF events, namely 19 (100\%) Regencies / Cities, and in 2017 there were 19 (100\%) Regencies / Cities that had DHF events. So it can be concluded that the incidence of DHF from 2014-2017 there were 74 (97.4\%) districts / cities that had dengue events, while there were no DHF events there were 2 (2.6\%) districts / cities in West Sumatra Province namely Mentawai in 2014 and 2015. Researchers assume, the presence of dengue in the province of West Sumatra is caused because cases of dengue fever increase along with the development of the vector.mosquito Aegypt Aedesthat lives in clean water. The highest DHF incidence in this study was found in Padang City, this was due to the high population density and high population mobility. In addition, the complete health facilities owned by the City of Padang make patients outside the City of Padang who suffer from DHF go to Padang, causing a possible cause of DHF from patients who come from outside the City.

\subsubsection{Population Density}

Results of research conducted by researchers, obtained that 76 samples, population density from 2014-2017 have four categories, namely non-dense (0-50 inhabitants), less dense (51250 inhabitants, quite dense (251-400 inhabitants) and very dense> 410 inhabitants). In 2014 the highest population density was in the less dense population category (51-250 inhabitants), which was found in $9(47.4 \%)$ districts / cities. In 2015 the highest population density was in the less dense population category (51-250 inhabitants), which was found in 9 (47.4\%) districts / cities. In 2016 the highest population density was in the less dense population category (51-250 inhabitants), which was found in nine (47.4\%) districts / cities. In addition, in 2017 the highest population density is still in the category of less dense population (51-250 people) which is found in $9(47.4 \%)$ districts / cities. So it can be concluded that during the last 4 years the highest population density was found in the category of less dense population (51-250 inhabitants), namely 36 (47.4\%) districts / cities in West Sumatra Province. Researchers assume, population density in West Sumatra Province can also be influenced by high population mobility caused by workers. Population density can have an impact on the quality of life of the community where high 
population density can reduce the quality of the population (education, health, income and employment). In this study, there is a dense population in the city of Bukittinggi this is due to the small area and the city of Bukittinggi is a city of education and tourism so that many people who want to live in the city. Less dense population is in the Mentawai Islands because Mentawai is located in a distant archipelago and transportation to it can only use ships. Mentawai Islands often occur earthquakes so that residents are afraid to settle in the Mentawai Islands.

\subsubsection{Rainfall}

Results of research conducted by researchers, obtained that 76 samples, rainfall from 2014-2017 as four characteristics of rainfall, namely low rainfall $(0-100 \mathrm{~mm})$, medium rainfall (101-300 mm), rainfall high (301-500 mm), and very high rainfall (> $500 \mathrm{~mm})$. In 2014 the highest rainfall was found in 15 (78.9) districts / cities in the medium rainfall (101-300). In 2015 the highest rainfall was found in 15 (78.9) districts / cities in the medium rainfall (101-300 mm). In 2016 the highest rainfall was found in 13 (768.4) districts / cities in the medium rainfall (101-300 $\mathrm{mm}$ ). And in 2017 the highest rainfall is found in 15 (78.9) districts / cities are in the medium rainfall $(101-300 \mathrm{~mm})$. So it can be concluded during the last 4 years there are 58 (76.3) districts / cities that are in medium rainfall $(101-300 \mathrm{~mm})$. Researchers assume, Indonesia has a tropical climate that is good for animal and plant growth. The tropical climate has 2 seasons namely the rainy season and the dry season. This also makes Indonesia, especially the Province of West Sumatra as a place for developing diseases, especially diseases carried by vectors such as mosquitoes. The rainy season can affect the development of mosquitoes if it is $140 \mathrm{~mm}$, but if high rainfall can wash away mosquito development sites so that mosquito breeding is disrupt. In the dry season it can also increase mosquito breeding, this is because in the dry season where puddles are calmer and mosquitoes can breed more. Whereas the regency / city in West Sumatra Province experiences rain almost every month.

\subsubsection{Trend of DHF Incident}

Seen from the trend of DHF events in West Sumatra Province from 2014-2017 experienced fluctuating changes, almost every regency / city has a DHF case, where in 2014 Padang City was the highest city in 1 with DHF incidence cases ie there were 666 cases, Pesisir Selatan is the highest of 2 namely 282 cases, Tanah Datar is the highest of 3 namely 279 cases, and for which there is no DHF incident found in Mentawai. In 2015 the city of Padang was still the highest city in which there were DHF cases, namely 1126 cases, Tanah Datar was the highest 2, there were 396 cases, the highest religion was 3, there were 280 cases, and there were no DHF events in Mentawai. In 2016, Kota Padang was the city that still had the highest 1 case of DHF, namely 991 cases, Agam was the highest 2, there were 438 cases, the highest Dhamasraya was 3, there were 349 cases, while the lowest cases in 2016 were in Mentawai with 22 cases. In 2017 the city of Padang is still ranked first with the highest cases of DHF that is 608 cases, Pasaman is the 
highest 2, there are 326 cases, South Coastal highest is 3, there are 284 cases and the lowest is in Mentawai with 1 DHF incident. Therefore, it was concluded from 2014-2017 Padang City is the city that has the highest incidence of DHF during the last 4 years, and Mentawai has the lowest case over the past 4 years. Researchers assume, the incidence of dengue in the province of West Sumatra in 2014-2017 Padang is a city that has the highest incidence of dengue during the last 4 years, and Mentawai has the lowest case over the past 4 years. Due to the dense population and high population mobility. In addition, the complete health facilities owned by the City of Padang make patients outside the City of Padang who suffer from DHF go to Padang, causing a possible cause of DHF from patients who come from outside the City. Another factor is caused by shuttle immigration because of the large number of students from outside Padang who are studying in Padang, so that dengue infection is increasing.

\subsubsection{Population Density Trends}

Viewed from the trend of population density in West Sumatra Province from 2014 to 2017 experiencing fluctuations, where the highest population density in 2014 was 1 in Bukittinggi by 4773.81 people, the highest population density 2 was in Padang Panjang City of 2182.96 inhabitants, the highest population density 3 was in Payakumbuh City of 1562.73 inhabitants, and the lowest population density was in Mentawai of 13.91 inhabitants. In 2015, the highest population density 1 was in Bukittinggi at 4858.2 people, the highest population density 2 was in Padang Panjang City at 2212.3 people, the highest population density 3 was in Payakumbuh City at 1589.28 people, and the lowest population density there are in Mentawai amounting to 14.19 inhabitants. In 2016, the highest population density 1 was in Bukittinggi City with 4941.16 inhabitants, the highest population density 2 was in Padang Panjang City with 2248.35 inhabitants, the highest population density 3 was in Payakumbuh City with 1613.91 inhabitants, and the lowest population density there are in Mentawai amounting to 14.47 inhabitants. In addition, in 2017 the highest population density 1 is still in Bukittinggi City by 5023.9 people, the highest population density 2 is in Padang Panjang City by 2279.22 people, the highest population density 3 is in Payakumbuh City by 1638.93 people, and population density the lowest found in Mentawai with 14.75 inhabitants. Therefore, it was concluded that the population density during the last 4 years the highest population is in the city of Bukittinggi where every year has increased, and the lowest density is found in Mentawai. Researchers assume population density over the past 4 years in West Sumatra Province, where the highest population is in the City of Bukittinggi where each year has increased, and the lowest density found in Mentawai. Due to the small area and Bukittinggi City is a city of education and tourism, so many people who want to live and visit in the city. Less dense population is in the Mentawai Islands because Mentawai is located in a distant archipelago and transportation to it can only use ships. Mentawai Islands often occur earthquakes so that residents are afraid to settle in the Mentawai Islands. The above has a chance for transmission of dengue events. 


\subsubsection{Rainfall Trends}

Viewed from the trend of rainfall in West Sumatra Province from 2014-2017 experiencing fluctuations, in 2014 the highest rainfall was 1 in the city of Padang which is $337 \mathrm{~mm}$ which is in the characteristics of high rainfall, the highest rainfall 2 found in Padang Pariaman, which is $320 \mathrm{~mm}$ which is in high rainfall, the highest rainfall 3 is in West Pasaman which is 313 $\mathrm{mm}$ which is in high rainfall, and the lowest is in Payakumbuh City which is $137 \mathrm{~mm}$ which is in medium rainfall. In 2015 the highest rainfall 1 was in West Pasaman which was $368 \mathrm{~mm}$ which was in the characteristics of high rainfall, the highest rainfall 2 was in Kota Pariaman which was $327 \mathrm{~mm}$ which was in high rainfall, the highest rainfall 3 was in Padang Pariaman which was 318 $\mathrm{mm}$ which is in high rainfall, and the lowest is in Sawah Lunto City which is $88 \mathrm{~mm}$ which is in low rainfall. In 2016 the highest rainfall 1 was in the city of Padang Panjang which is $502 \mathrm{~mm}$ which is in the characteristics of very high rainfall, the highest rainfall 2 was in the city of Padang which was $425 \mathrm{~mm}$ which was in the high rainfall, the highest rainfall 3 was in Kota Pariaman namely $381 \mathrm{~mm}$ which is in high rainfall, and the lowest is in Sawah Lunto City which is $141 \mathrm{~mm}$ which is in medium rainfall. And in 2017 the highest rainfall 1 is in Padang City which is $411 \mathrm{~mm}$ which is on the characteristics of high rainfall, the highest rainfall 2 is in Padang Pariaman which is $375 \mathrm{~mm}$ which is at high rainfall, the highest rainfall 3 is in West Pasaman namely $348 \mathrm{~mm}$ is in the high rainfall, and the lowest is in Bukittinggi City, which is $120 \mathrm{~mm}$ in the medium rainfall. So it can be concluded that for the past 4 years, the highest rainfall 1 in the past 2 years was found in Padang City, 2 highs in Padang Pariaman, and the lowest rainfall in 2 years behind was found in Sawah Lunto City. Researchers assume, high rainfall in this study from 2014-2017 is in the city of Padang Panjang, this is due to the city of Padang Panjang located in the highlands precisely below the foot of Mount Singgalang and Mount Merapi. While the highest rainfall 1 in the past 2 years is found in the city of Padang, high 2 in Padang pariaman. Low rainfall is found in Sawah Lunto City because this is Sawah Lunto City located in the highlands, where if the higher a place, the lower the rainfall.

\subsection{Bivariate Analysis}

\subsubsection{Population Density}

Based on the results of the study it was that the population density with the occurrence of DHF is not significant with a sig value of 0.913 . It means $0.913>0.05$ and thus the correlation between the two variables is not significant, so that the strength of the relationship cannot be analyzed. Researchers assume, almost every year there is an increase in population density but accompanied by fluctuating DHF events. This is likely to occur because of the influence of other factors that can also affect the incidence of DHF. Dense population can affect the occurrence of 
DHF because the Aedes aegypty mosquito is domestic because of its short flying distance (100 meters). In this study, the population density is in the less dense category, meaning that the density of the less dense population is not at risk for dengue transmission due to short mosquito flight distances.

\subsubsection{Rainfall}

Based on the results of the study it was that the rainfall with the occurrence of DHF is significant with a sig value of 0.015 . It means $0.015<0.05$ and thus the correlation between the two variables is significant, with a correlation coefficient value of 0.279 which means that the correlation coefficient is weak with the direction of a positive relationship. Researchers assume the strength of a weak relationship between rainfall and the incidence of DHF can occur due to high rainfall can actually eliminate Aedes aegypti mosquito breeding places so that the population of Aedes aegypti mosquitoes can reduced. Aedes aegypti mosquito population that is reduced will reduce the risk of DHF events. Increasing mosquito-breeding sites because disposable places such as cans, plastic cups, plastic wrappers, old tires and the like which are discarded or placed irregularly in places where water can be flooded which allows the number of dengue cases can also increase.

It is concludesion that the characteristics of rainfall in this study are the characteristics of medium rainfall (101-300 $\mathrm{mm}$ ) where the range of rainfall can increase mosquito density, each millimeter can increase mosquito density by one tail. The highest DHF incidence in West Sumatra Province every year does occur during the rainy season. In addition, Kota Padang in the last 2 years has moderate rainfall. This means that the city of Padang is at risk for the highest DHF transmission. The higher the rainfall in the city of Padang, the incidence of DHF increases. It was expected that all health center in Padang would carry out a DHF prevention program with (Mosquito Eradication Eradication), and Three M Plus.

\section{Conclusions}

The results of research conducted on 76 samples in the province of West Sumatra in 2014 - 2017 was concluded that the frequency distribution of DHF occurrence in 2014-2017 is obtained. Based on the results of the study, it can be seen that from 76 samples, there were 74 (97.4\%) districts / Cities where there were DHF events, and for which there were no DHF events, there were $2(2.6 \%)$ Regencies / Cities in West Sumatra Province, namely Mentawai in 2014 and 2015. Obtained a frequency distribution of Population density in 2014 - 2017 were 76 samples, that during the last 4 years the highest population density was found in the category of less dense population (51-250 inhabitants), namely 36 (47.4\%) districts / cities in West Sumatra Province. Rainfall frequency distribution obtained in 2014-2017 is 76 samples, during the last 4 years there 
were 58 (76.3) districts / cities that are in medium rainfall $(101-300 \mathrm{~mm})$. Obtained the trend of DHF events in 2014-2017 Padang City is the city that has the highest DHF incidence over the past 4 years, and Mentawai has the lowest case over the past 4 years.

\section{References}

[1]. BMKG kelas II Padang Pariaman, Dinas kesehatan West Sumatera, Profil Kesehatan West Sumatera 2014 dan 2017

[2]. BMKG. 2014. Data Curah Hujan . Padang Pariaman: Stasiun Klimatologi Kelas II Padang Pariaman

[3]. BMKG. 2015. Data Curah Hujan . Padang Pariaman: Stasiun Klimatologi Kelas II Padang Pariaman

[4]. BMKG. 2016. Data Curah Hujan . Padang Pariaman: Stasiun Klimatologi Kelas II Padang Pariaman

[5]. BMKG. 2017. Data Curah Hujan . Padang Pariaman: Stasiun Klimatologi Kelas II Padang Pariaman.

[6]. Widoyono. 2011. Penyakit Tropis. Jakarta: PT Gelora Aksara Pratama.

[7]. Suhermanto, S. 2017. Demam Berdarah Dengue Berdasarkan Kepadatan Penduduk Dan Curah Hujan. Bahana Kesehatan Masyarakat.

[8]. Kementrian kesehatan Republik Indonesia. 2014. Profil Kesehatan Indonesia. Jakarta: Kementrian Kesehatan Republik Indonesia.

[9]. Kementrian kesehatan Republik Indonesia. 2015. Profil Kesehatan Indonesia. Jakarta: Kementrian Kesehatan Republik Indonesia.

[10]. Kementrian kesehatan Republik Indonesia. 2016. Profil Kesehatan Indonesia. Jakarta: Kementrian Kesehatan Republik Indonesia.

[11]. Kementrian kesehatan Republik Indonesia. 2017. Profil Kesehatan Indonesia. Jakarta: Kementrian Kesehatan Republik Indonesia. 